\title{
"Informal" food traders and food security: experiences from the Covid-19 response in South Africa
}

\author{
Marc C. A. Wegerif ${ }^{1}$ (D) \\ Received: 5 May 2020 / Accepted: 30 June 2020 / Published online: 7 July 2020 \\ (C) International Society for Plant Pathology and Springer Nature B.V. 2020
}

\begin{abstract}
This opinion piece looks at the substantial role of informal traders in ensuring food security, and other economic and social goods in South Africa and how they have been impacted by Covid-19 and responses to it. The state responses have reflected a continued undervaluing and undermining of this sector to the detriment of the traders themselves, their suppliers, and their customers. There is a need for a new valuing of the sector that would recognise and build on its mode of ordering and key contributions to society. This needs to include: shifting the narrative about the actors involved and challenging the concept of "informal"; planning and regulating to ensure more space for owner-operated small-scale food retailers; and putting in place a social-safety net to support them in times of crisis.
\end{abstract}

Keywords Informal economy $\cdot$ Food markets $\cdot$ Food systems $\cdot$ Food security $\cdot$ Covid-19 $\cdot$ Small-scale retailers

\section{Introduction}

When decision makers in South Africa responded to the Covid-19 crisis, the needs of "informal" traders and their important contribution to food security were clearly not considered. This reflects a lack of knowledge about the sector and entrenched negative attitudes towards it. This article provides a brief picture of the sector from my ongoing research and shares experiences of the lockdown based on telephonic discussions and online communications I had with key informants and existing research participants.

\section{The nature and scale of the "informal" food sector}

Despite the high concentration of corporate ownership in the food and grocery sector in South Africa, especially when compared to other African countries, the "informal food sector" still accounts for 40 to $50 \%$ of sales and is worth around R360

Marc C. A. Wegerif

marc.wegerif@up.ac.za

1 Department of Anthropology and Archaeology, University of Pretoria, Pretoria, South Africa billion (US\$20 billion) a year (CCSA 2019; Pick-N-Pay 2019; Greenberg 2015, 2017). This sector - made up of small-scale owner-operated enterprises who sell food of various kinds, including street traders, hawkers, spaza ${ }^{1}$ shops, and bakkie traders ${ }^{2}$ - employs more people than the formal food and grocery sector.

Around $70 \%$ of households in poorer neighbourhoods in South Africa source some food from the informal sector (Battersby et al. 2016). This is because these enterprises, in South Africa and elsewhere (Wegerif and Hebinck 2016), make food accessible through: 1) selling close to where people live and work; 2) the convenience of long operating hours; 3 ) selling in flexible quantities that respond to what people can afford; 4) lower prices than large formal retailers; and 5) providing interest free credit to regular customers. In research on fresh-produce supplies to the city of Johannesburg I have found street traders selling vegetables - such as tomatoes, onions, and cabbage - at half or one-third of the price of the same produce at supermarkets.

In addition to making food accessible, informal traders, operating in territorial food systems (CSM 2016), maximise economic and ownership opportunities, creating multiplier effects into local communities they are part of. They spend more

\footnotetext{
${ }^{1}$ The spaza in South Africa is a small local grocery store normally operating from people's homes in residential areas.

${ }^{2}$ People selling mostly fresh produce from the back of their pick-up trucks.
} 
of their operating budget and profits on local businesses from farmers, to local shops, and bars. They also contribute to social integration, including for migrants, and are the 'eyes on the street' (Jacobs 1961) that create safer and more hospitable public spaces.

By contrast, the owners of corporate food retailers often have no particular interest in food, or the country - let alone the locality - where they are selling. Increasingly food is just another commodity invested in if it gives good returns, bought, shipped and sold wherever profit can be maximised. For example, South Africa's biggest supermarket group, Shoprite Holdings Limited, is $82 \%$ owned by banks, brokers, retirement and mutual funds, and private companies and $61 \%$ of the shareholders are from outside South Africa (Shoprite 2019).

Informal food traders are an essential part of a wider food system going from input suppliers, to farmers, and to the final eaters. The Johannesburg Fresh Produce Market is the biggest in South Africa, with annual sales of close to R8 billion (US\$444 million). The agents - large formal businesses that handle all transactions at the market - estimate that $50 \%$ of their sales go to the informal sector, indicating that the informal fresh produce sector in the Johannesburg area is worth at least R4 billion (US\$222 million) a year. Harm to the informal sector will have negative effects throughout the agri-food system, but worse for small-scale farmers. Small-scale black farmers I have interviewed in South Africa often find better returns selling to informal traders, compared to supplying formal retail chains. Other studies in South Africa and beyond, have found that having trading, processing and retailing operations of a similar scale, run by people with common cultural repertoires, creates an enabling environment for small-scale farmers (Wegerif 2018; CSM 2016; Manyelo et al. 2014).

\section{Impacts on informal traders and their customers of COVID-19 and responses to it}

On 23rd March 2020, the President of South Africa announced a national lockdown effective from midnight on 26th March. All people except essential services workers, which include those in food supply, where to stay at home and the police and army were deployed to enforce this. With the announcement of a state of disaster a week earlier and growing awareness about the spread and risks of Covid-19, business had already started slowing for informal food traders and many others. Despite food being considered an essential service, street traders, including those selling food, were stopped from operating and lost all income. Fresh produce traders lost all stock that they hadn't sold or eaten. As well as immediate challenges of poverty and hunger, it won't be easy for these business to start operating again once the lockdown is lifted, given the depletion of their capital. As one street trader told me:
"If I haven't sold anything, if I am just sitting and haven't got that little income, the money that I was saving while selling, it is that money that I am eating now."

In terms of the regulations - passed under the Disaster Management Act, 2002 (Act No. 57 of 2002) - spaza shops were allowed to operate, but had to get permits. Despite this, statements by a government minister, which implied that only South African owned shops would be allowed to open, and confusion around the varied permitting systems, prevented many spaza shops from working. Some security forces that were either not well informed or took advantage of the situation, tried to extort bribes or close shops owned by non-citizens (Sizani 2020).

With food traders stopped from operating, many people had to travel further to get food. This not only resulted in increased transport costs, but also undermined the purpose of the lockdown as people faced greater risks of contracting Covid-19 on public transport and from queueing in the supermarkets that were open. A resident of a township outside Johannesburg explained to me how there were no street traders left operating and $80 \%$ of the local spaza shops had not managed to get permits to operate. He, like many other residents of this township of around 250,000 people, had to use public transport to get to the two open supermarkets in the area. These were very crowded resulting in people not following the social distancing protocols. When he could he chose instead to take a longer journey, at greater expense, to a less crowded supermarket in a wealthier area.

An ongoing survey of the cost of a household food basket, for women in low income areas of Pietermaritzburg, found the cost increased by $7.8 \%$ in just two months of the lockdown from March to May 2020. This compares with a $13.8 \%$ increase for the whole year from May 2019 to 2020 and includes items like onions that went up by $58 \%$ and cabbage by $22 \%$ (PMBEJD 2020b). One reason for the increases is the absence of street traders where these women would normally buy vegetables at lower prices and benefit from other services, such as leaving their shopping bags while searching for good deals (PMBEJD 2020a).

It is too early to have results from representative national surveys, but it seems clear that we will see increased levels of food and nutrition insecurity (undernourishment and obesity) due to the loss of incomes, the loss of more accessible and affordable food retailing options, and new transport costs. Large-scale state and other interventions, in the form of food parcel distribution and increased grants, are unlikely to fully overcome the negative impacts, given factors such as the absence of fresh produce in the food parcels and some of the most vulnerable, such as non-citizens, being missed.

A number of civil society organisations pushed for changes and the national government did respond with an amendment to the regulations on 2nd April (Government Notices No. R.419 of 2 April 2020). This made it clear that informal food traders could operate "with written permission from a municipal authority". 
Thousands of street traders and hawkers went to municipal offices to get permits, with mixed results. Many got permits and started operating, but some municipalities had no permitting system in place and struggled to devise an approach in the middle of a crisis situation. Some municipalities became overwhelmed and struggled to identify the informal traders who had been operating before the lockdown, and others put in place unreasonably obstructive requirements. There were later reports of food traders being harassed and arrested by security forces despite having permits.

The informal traders I spoke to around Johannesburg had varied experiences. Some got permits and were doing reasonably good business, some were refused permits, others chose to stay home for their own safety. One who got a permit and returned to business after the regulations were amended later had the police confiscate all his stock as they said he had to renew the less than two week old permit and refused to wait while he did so. Nevertheless he got a new permit on the same day, bought new, albeit more limited stock, and is building up the business again.

Some spaza shop owners also continued to face challenges, including with getting permits in areas where these had not previously been required and with directives that didn't fit their operations. An example was the banning of anyone from sleeping at shops, despite most such shops being in people's homes and security concerns making it the norm for the shop owner or worker to stay there.

Farmers and with them farm workers are also impacted by the loss of demand. While local informal food markets have dramatically declined, farmers relying on exports have been hit by transport interruptions, and those selling high value produce to the hotel and restaurant market have also lost their incomes.

\section{Reflections}

Many politicians and officials embrace a modernization paradigm that views the corporate owned supermarkets and their supply chains as more desirable and hygienic. A view of course enhanced by enormous spending on advertising and lobbying by those very corporations. During Covid-19 related restrictions people still have to be able to acquire food, which entails some risk, but there is no reason to believe supermarkets are the safer option. Supermarkets had to introduce a wide range of new hygiene measures, but have still become one of the main sites of Covid-19 transmission in South Africa (Evans 2020; Kassen et al. 2020). Street traders and local spaza shops, especially if assisted by government, can create a reasonably safe environment ${ }^{3}$ and have the added advantage of reducing the

\footnotetext{
${ }^{3}$ The organization Women in Informal Employment: Globalizing and Organizing has produced a Covid-19 guide for the safe operation of informal traders (WIEGO 2020)
}

need to travel and the crowding that results when only a few shops are open.

The obstacles to the creation of an hygienic environment that do exist in some market areas are related to poor infrastructure, such as a lack of water, sanitation, and shelter. The lack of investment in such facilities is another outcome of the undervaluing of these areas and the people who work and shop in them. What is needed is investment in supportive infrastructure on an urgent and longer-term basis as part of efforts to ensure food security and more equitable local economic and social development. Changes are also needed in planning and regulations to create more space specifically for small-scale food traders and aimed at ensuring fresh produce is available within walking distance of all people's homes. There are examples of regulations that do this, such as the "crawling peg" town planning policy implemented in Nanjing, China, that reserves space for public markets and small-scale local fresh produce (Zhong et al. 2019).

Shifting the narrative on these important owner-operated enterprises requires more research, especially by social scientists, to unpack how these actors organise themselves and how they could be better supported in ways that build on their existing practices. Also needed is a change of language, including moving away from the concept of "informal". Describing people and their enterprises by what they are not has a built in assumption of their insignificance and that the other that they are not - formal - is superior. This is part of what leads them to being looked down on by policy makers who leave them out of their emergency plans and local policemen who think nothing of taking their stock. It leads to simplistic interventions that aim to formalise them in the image of large-corporations, rather than building on how they operate and the benefits of that.

I am not sure of the best terminology; these are shop owners, street traders, and hawkers who operate in what I have called symbiotic relations (Wegerif 2018). Core characteristics that are central to their positive contribution, and need to be built on, include that they are: owner operated; small-scale; embedded in their local communities; have low barriers to entry (especially in capital and bureaucratic requirements); and where successful they operate in relations of interdependence with others.

The last months have shown the vulnerability of these traders in times of crisis and highlighted the need for social safety nets that respond to their needs and circumstance. These are hard-working people that do not need charity, but could benefit from a well-structured and government supported scheme that they can contribute to the financing of. Such schemes are there for the formally employed and their employers, such as the South African Unemployment Insurance fund that has, despite its many challenges, paid out R16.5 billion (US\$916 million) in the first two months of the Covid-19 lockdown (SANews 2020). The street traders I 
know understand the importance of saving for future events, but often find the formal systems inaccessible. They use informal savings businesses and are part of family funeral societies and other savings groups. It is these practices that need to be learnt from and built on to create a safety net that can work for this sector.

The experiences during this time of Covid-19 have confirmed the importance of these small-scale, owner-operated, and local actors in the food system. There is a clear need to do more to enable them to reach their full potential in times of normalcy and to be ready for times of crisis. The challenge is to do this in ways that don't undermine their mode of operating and their positive economic and social impacts.

Acknowledgments This paper drew on the development of a position paper for the C19 People's Coalition that a number of organisations and individuals contributed to. It was also informed by conversations with street traders and students who shared their lived experiences under the Covid-19 lockdown in South Africa. I appreciate the feedback received from two anonymous reviewers.

\section{Compliance with ethical standards}

Conflict of interest The author declares that they have no conflict of interest.

\section{References}

Battersby, J., Marshak, M., \& Mngqibisa, N. (2016). Mapping the invisible: The informal food economy of Cape Town, South Africa. In J. Crush (Ed.), Urban food security series (Vol. 24). Cape Town: African food security urban network.

CCSA. (2019). The grocery retail market inquiry final report. Johannesburg: Competition Commission South Africa.

CSM (2016). Connecting Smallholders to Markets: An Analytical Guide. International Civil Society Mechanism, Hands On the Land Alliance for Food Sovereignty (Vol. 12). Rome, Italy: Civil Society Mechanism, World Committee on Food Security.

Evans, J. (2020). Covid-19: Outbreaks at supermarkets a concern for Western cape government. https://www.news24.com/SouthAfrica/ News/covid-19-outbreaks-at-supermarkets-a-concern-for-westerncape-government-20200416. Accessed 27 April 2020.

Greenberg, S. (2015). Corporate concentration and food security in South Africa: Is the commercial agro-food system delivering? Cape Town: Institute for Poverty, Land and Agrarian Studies, University of the Western Cape.

Greenberg, S. (2017). Corporate power in the agro-food system and the consumer food environment in South Africa. The Journal of Peasant Studies, 44(2), 467-496.

Jacobs, J. (1961). The death and life of great American cities. New-York: Vintage.

Kassen, J., Felix, J., \& Brandt, K. (2020). Over 200 Western cape supermarket employees test positive for coronavirus. https:/ewn.co.za/ 2020/04/25/over-400-western-cape-supermarket-employees-testpositive-for-coronavirus. Accessed 27 April 2020.

Manyelo, K., Van Averbeke, W., \& Hebinck, P. (2014). Smallholder irrigators and fresh produce street traders in Thohoyandou,
Limpopo Province, South Africa. In P. Hebinck, J. D. van der Ploeg, \& S. Schneider (Eds.), Rural development and the Construction of New Markets (pp. 131-150).

Pick-N-Pay. (2019). Integrated annual report. Cape Town: Pick-N-Pay Stores Limited.

PMBEJD (2020a). Food prices, social grants and Covid-19. Research Report, 28 April 2020. Pietermaritzburg: Pietermaritzburg Economic Justice and Dignity.

PMBEJD (2020b). Food, hunger, and Covid-19. Research Report, 26 May 2020. Pietermaritzburg: Pietermaritzburg Economic Justice and Dignity.

SANews (2020). UIF COVID-19 fund pays out R16.5 billion. SANews. gov.za. Pretoria, South Africa: Government Communication and Information System, RSA.

Shoprite. (2019). Annual financial statements 2019. Cape Town: Shoprite Holdings Limited.

Sizani, M. (2020). Covid-19: Police shut immigrant-owned spaza shops after Minister's xenophobic statement. https://www.groundup.org. za/article/covid-19-police-shut-down-immigrant-owned-spazashops-after-minster-ntshavhenis-xenophobic-statement/. Accessed 27 April 2020.

Wegerif, M. C. A. (2018). An ethnographic exploration of food and the city. Anthropology Today, 34(5), 16-19. https://doi.org/10.1111/ 1467-8322.12460.

Wegerif, M. C. A., \& Hebinck, P. (2016). The symbiotic food system: An 'Alternative'Agri-food system already working at scale. Agriculture, 6(3), 40. https://doi.org/10.3390/agriculture6030040.

WIEGO (2020). COVID-19 guidelines for informal traders (in streets, markets and spaza shops). https://www.wiego.org/sites/default/ files/resources/file/WIEGO_COVID19_SVs_whatssapp_24April. pdf. Accessed 27 April 2020.

Zhong, T., Si, Z., Crush, J., Scott, S., \& Huang, X. (2019). Achieving urban food security through a hybrid public-private food provisioning system: The case of Nanjing, China. Food Security, 11(5), 1071-1086.

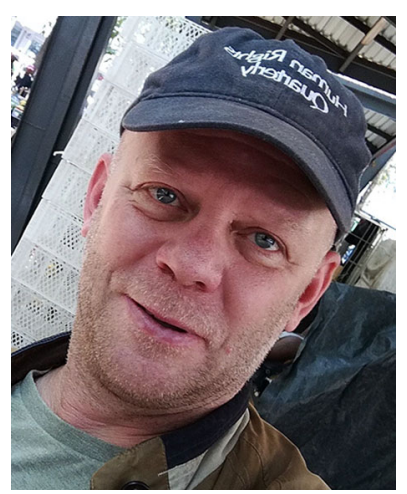

Dr. Marc C. A. Wegerif I am a Lecturer in Development Studies at the University of Pretoria and carry out research on food systems, land rights, and agrarian issues. I have a particular interest in the symbiotic and non-corporate means of production and distribution of food that exist in Southern Africa with a focus on Tanzania and South Africa. I have worked on development issues in a range of organisations in South Africa and Internationally for about 30 years. My PhD is from Wageningen University. The focus of the research was on the food system that feeds the large and fast-growing city of Dar es Salaam. My Master's Degree was obtained cum laude in Land and Agrarian Studies at the University of the Western Cape. 